\title{
THE NUMERICAL ANALYSIS OF PILES' RESTRICTION ON FOUNDATION
}

\author{
Li Zhiyuan, Liang Ren-Wang, Zou Long-Sheng, Zhang Yanmei
}

Preliminary note

How can people predict the sedimentation of tall buildings and analyze the foundation rebound to protect underground utilities? This is the urgent problem in today's construction. To solve it, this paper is dedicated to analyzing how piles affect the foundation rebound value by using Mohr-Coulomb Model and the 3D emulation calculation software FLAC3D with 20-meter-deep foundation pits as an example. The study shows that the distribution pattern of the foundation rebound without piles is a convex curve while piles make the curve go corrugated with the foundation rebound value shrieking by $0,4 \div 0,6$. Also, parameters such as the distance of the piles and diameter of the piles and length of the piles have an effect on the value in a way that the increasing distance lowers the piles' restriction on the foundation rebound value. Therefore, this paper suggests that the largest distance between piles should be no more than $6 d$ when the restricted extent of the value is about $0,23 \div 0,37$. Raising the diameter and length of the piles (no more than 1,25 times of the digging depth) can restrict rebound effectively. Therefore, this paper concludes useful parameters in pile design, proves its mechanism for restriction on foundation rebound, and provides analytical basis for optimization of the piles.

Keywords: Mohr-Coulomb Model principle; numerical imitation; piles; rebound

\section{Numerička analiza ograničenja pilota kod temeljenja}

Prethodno priopćenje

Kako je moguće predvidjeti taloženje visokih zgrada i analizirati pomak temelja kako bi se zaštitile podzemne komunalije? To je urgentan problem u današnjoj izgradnji. U svrhu njegovog rješenja, u ovom se radu istražuje kako piloti utječu na vrijednost pomaka temelja primjenom Mohr-Coulomb Modela i 3D računarskog programa FLAC3D s $20 \mathrm{~m}$ dubokim iskopima temelja kao primjerom. Analiza pokazuje da je distribucijski uzorak pomaka temelja bez pilota konveksna krivulja, a da s pilotima krivulja postaje valovita uz porast vrijednosti pomaka temelja za $0,4 \div 0,6$. Isto tako parametri poput udaljenosti pilota, promjera pilota i njihove dužine utječu na tu vrijednost na način da veći razmak snižava ograničenje pilota na vrijednost pomaka temelja. Stoga se u radu predlaže da najveći razmak između pilota ne bi trebao biti veći od $6 d$ kad je ograničeni iznos vrijednosti oko $0,23 \div 0,37$. Povećanje promjera i dužine pilota (ne više od 1,25 puta dubine kopanja) može učinkovito ograničiti pomak. Prema tome, u radu se daju korisni parametri za konstrukciju pilota, dokazuje njihovo djelovanje na mehanizam za ograničenje pomaka temelja i pruža analitička osnova za optimizaciju pilota.

Ključne riječe: numerička imitacija; piloti (šipovi); pomak; princip Mohr-Coulomb Modela

\section{Introduction}

In recent years, the flourishing tall building construction has been driving rapid development of deep foundation pits. However, the deeper the pits are, the stronger the rebound effect is. Therefore, how to prevent rebound to predict sedimentation of buildings and protect underground utilities has become a hot issue. Many researches have shown that piles can keep down rebound effectively, but few have talked about how to design the piles properly. This paper aims to discuss the issue. What are piles? They are heavy columns used in construction to bear the force in a building. Mohamad H. Hussein M. ASCE etc. [1] research the pile drivability and bearing capacity in high-rebound soils, and a correlation between the static load test and dynamic test results is presented; Fauzi Jarushi etc. [2] research that high-displacement piles have rebounded significantly while undergoing an extremely small permanent set per hammer blow in certain soils. This phenomenon, called high pile rebound (HPR) has occurred in many areas of North America. Fauzi Jarushi etc. [3, 4, 5] research that an equation for predicting rebound, based on $R_{f}$ and $u_{2}$, was developed, and the results showed the ability to predict pile rebound during designate large displacement piles are to be driven. Yang Y. etc. [6] indicate that the structure of anchored and statically pressed piles with axial prestress is presented. The calculation of axial prestress is given by discussing the reason of rebounding of newly added piles. The pressing force can be increased if the total pile length is shorter than designed.

\section{Construction of the model}

To construct a model applicable to the imitation and calculation of FLAC3D requires three steps. First, create a finite difference grid; second, define the parameters of constitutive model and the assigning materials; third, define boundary conditions and initial conditions. The grid determines the imitated geometry space; the constitutive model and the parameters control the reaction patterns of the model to external changes; the two kinds of conditions define the initial state of the model $[7,8,9]$.

In this model, homogeneous cohesive soil is applied without consideration of underground water. The foundation soil model applies Mohr-Coulomb Model and the parameters of the foundation soil are chosen according to engineering experience. Elasticity modulus $E$ is the variable. This paper also adopts formula $E=k p_{a}\left(\frac{\sigma_{3}}{p_{a}}\right)^{n}$ in Duncan-Chang constitutive model where soil tangent modulus changes according to minor principal stress in which $k=704, n=0,38, p_{a}$ is atmospheric pressure, $p_{a}=$ $101325 \mathrm{~Pa}$, and $\sigma_{3}$ is the minor principal stress. FLAC3D model, within the elastic range, is described by two elasticity constants: (bulk modulus) $K$ and (shear modulus) $G$. Their relationship with elasticity modulus $E$ and $v$ Poisson's ratio can be described in formula $K=\frac{E}{3(1-2 v)}$ and $G=\frac{E}{2(1+v)} . E$ and $G$ are variables here. The indexes of physical and mechanical properties of the adopted foundation soil are shown in Tab. 1. 


Table 1 Parameters concerning the soil
\begin{tabular}{|c|c|c|c|}
\hline $\begin{array}{c}\text { Poisson's ratio } \\
v\end{array}$ & $\begin{array}{c}\text { Cohesive } \\
\text { force } c / \mathrm{kPa}\end{array}$ & $\begin{array}{c}\text { Internal } \\
\text { friction angle } \\
\varphi /{ }^{\circ}\end{array}$ & $\begin{array}{c}\text { Density } \\
\rho / \mathrm{kg} / \mathrm{m}^{3}\end{array}$ \\
\hline 0,3 & 25 & 15 & 1800 \\
\hline
\end{tabular}

The imitation of piles applies the pile structure unit. Its parameters can be set referring to FLAC3D handbook, Xiao Zhaoran's suggestion [10], and engineering experience. The parameters of the pile structure adopted in this paper are shown in Tab. 2.

Table 2 Parameters about the pile

\begin{tabular}{|c|c|c|c|c|c|c|c|}
\hline \multirow[b]{2}{*}{$\begin{array}{l}\text { Elasticity modulus } \\
\qquad E / \mathrm{GPa}\end{array}$} & \multirow[b]{2}{*}{$\begin{array}{l}\text { Poisson's } \\
\text { ratio } v\end{array}$} & \multicolumn{3}{|c|}{ Tangential spring parameters } & \multicolumn{3}{|c|}{ Normal spring parameters } \\
\hline & & $\begin{array}{c}\text { Cohesive force } \\
c_{s} / \mathrm{kN} / \mathrm{m}\end{array}$ & $\begin{array}{c}\text { Friction angle } \\
\phi_{s} /{ }^{\circ}\end{array}$ & $\begin{array}{c}\text { Shear } \\
\text { stiffness } \\
k_{s} / \mathrm{GPa}\end{array}$ & $\begin{array}{c}\text { Cohesive force } \\
c_{n} / \mathrm{kN} / \mathrm{m}\end{array}$ & $\begin{array}{c}\text { Friction angle } \\
\phi_{n} /{ }^{\circ}\end{array}$ & $\begin{array}{c}\text { Shear stiffness } \\
k_{n} / \mathrm{GPa}\end{array}$ \\
\hline 30 & 0,3 & 182,8 & 10 & 130 & 150 & 10 & 1,3 \\
\hline $\begin{array}{c}\text { Cross sectional area } \\
\mathrm{A} / \mathrm{m}^{2}\end{array}$ & \multicolumn{2}{|c|}{$\begin{array}{c}\text { MOI of Y-axis } \\
I_{y} / \mathrm{m}^{4}\end{array}$} & \multicolumn{2}{|c|}{$\begin{array}{c}\text { MOI of Z-axis } \\
I_{z} / \mathrm{m}^{4}\end{array}$} & \multicolumn{2}{|c|}{$\begin{array}{c}\text { Polar MOI } \\
\mathrm{J} / \mathrm{m}^{4}\end{array}$} & $\begin{array}{c}\text { Outer parameter } \\
P / \mathrm{m}\end{array}$ \\
\hline 0,5024 & \multicolumn{2}{|c|}{0,201} & \multicolumn{2}{|c|}{0,201} & \multicolumn{2}{|c|}{0,402} & 2,512 \\
\hline
\end{tabular}

The working condition of the model is as follows. As the foundation pit is 20 meters deep, the research model is a square $[11,12] 180$ meters wide (9 times of the depth of the pit), 60 meters high ( 3 times of the depth), 2 meters long, and with the diaphragm wall 1,0 meter thick. To make the research more feasible, this paper adopts one fourth of the model as the research subject.

\section{The analysis of the numerical imitation}

The embedment depth of the piles is 20 meters; Poisson's ratio $v$ is 0,3 ; the number of piles put in the onefourth area of the foundation pit is $3 \times 3=9$; the diameter $d$ of the piles is $0,6 \mathrm{~m}, 0,8 \mathrm{~m}, 1,0 \mathrm{~m}, 1,2 \mathrm{~m}, 1,4 \mathrm{~m}$ respectively, the length of the piles $L, 10 \mathrm{~m}, 15 \mathrm{~m}, 20 \mathrm{~m}$, $25 \mathrm{~m}, 30 \mathrm{~m}, 35 \mathrm{~m}, 40 \mathrm{~m}$ respectively, their distance $s, 3 d$, $4 d, 5 d, 6 d, 7 d$ and $8 d$ respectively, their width $1,6 \mathrm{~m}, 8 \mathrm{~m}$, $9 \mathrm{~m}, 11 \mathrm{~m}$ respectively.
Then, given two grids with their density being $1,0 \mathrm{~m}$ and 1,5 $\mathrm{m}$ respectively, see the change of the maximum rebound value with and without piles. Compare the effects on the maximum rebound value of the piles put in the lattice and on the nodes. Set the breadth of the foundation pit $B$ as $9 \mathrm{~m}$, the diameter of the pile $d$ as $0,8 \mathrm{~m}$, the length $L$ as $25 \mathrm{~m}$, the embedment depth $20 \mathrm{~m}$, and Poisson's ratio $v$ as 0,3 . Given an intersection line of two surfaces $z=20 \mathrm{~m}, y=1,5 \mathrm{~m}$, see the changing pattern of the rebound value on the nodes of the line with and without piles. The digging of the foundation pit consists of seven stages, at each the depth of digging $\mathrm{z}$ is different, following a sequence of $2 \mathrm{~m}, 5,3 \mathrm{~m}, 8,6 \mathrm{~m}, 11,9 \mathrm{~m}, 15,2$ $\mathrm{m}, 18,5 \mathrm{~m}$ and $20 \mathrm{~m}$ respectively. The digging at each stage is described in Figs. 1 in 3D. Fig. 2 is the illustration of the fifth, sixth and seventh steps of Fig. 1 so that the effects of the piles on foundation pit rebound is more clearly seen.

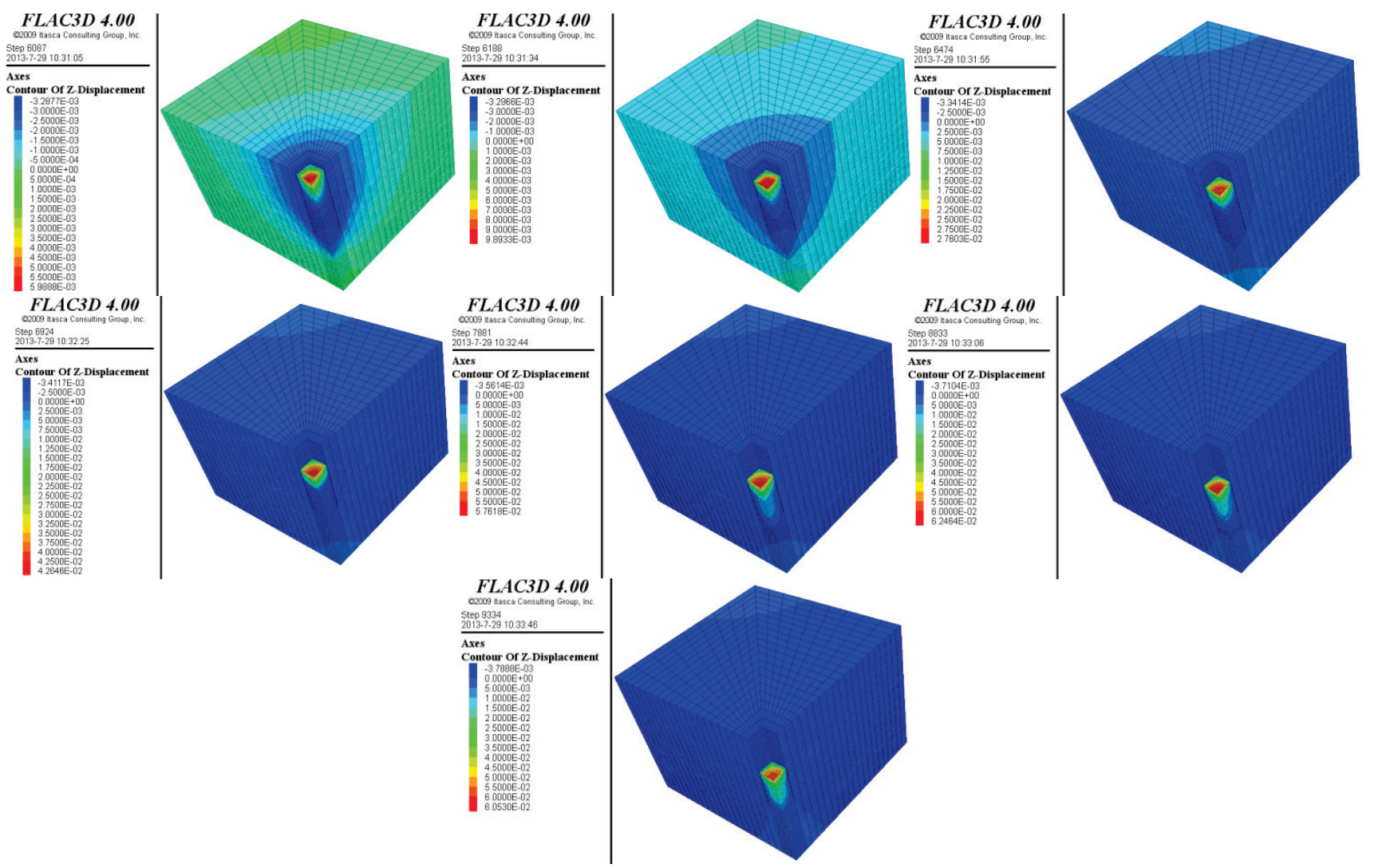

Figure $13 \mathrm{D}$ illustration of the digging steps of the foundation pit 


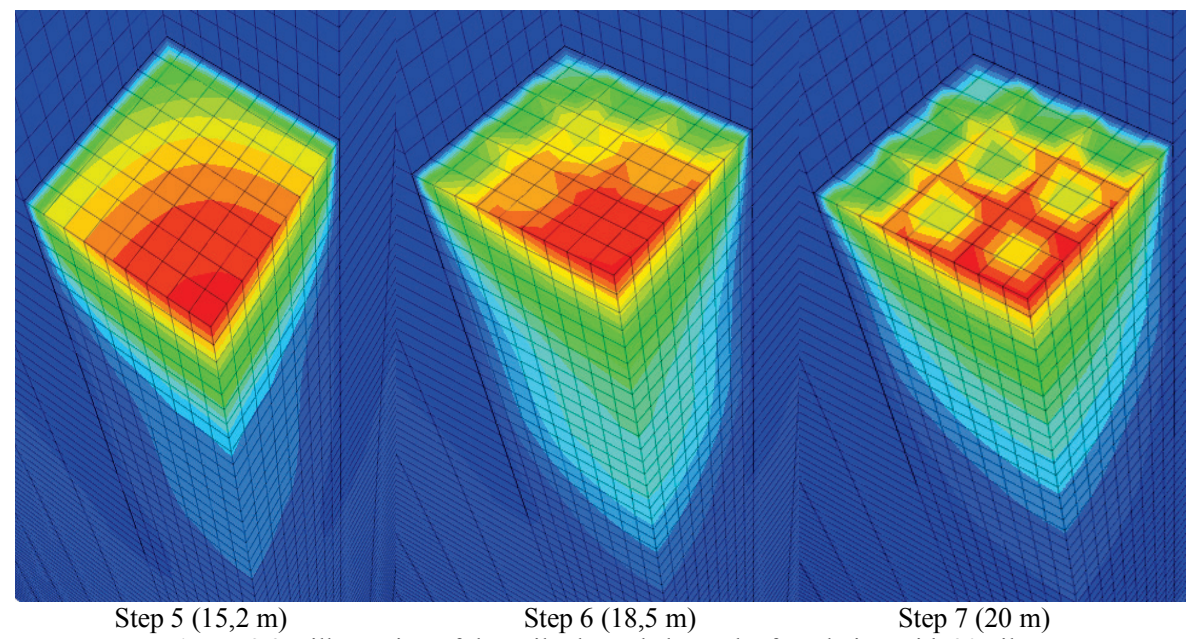

Figure 2 3D illustration of the soil rebound above the foundation with 20 piles

\subsection{Changing the density of the grid}

In (a) and (b), piles are set on the nodes with the density of grid being $1,5 \mathrm{~m}$. In (c) and (d), the piles are

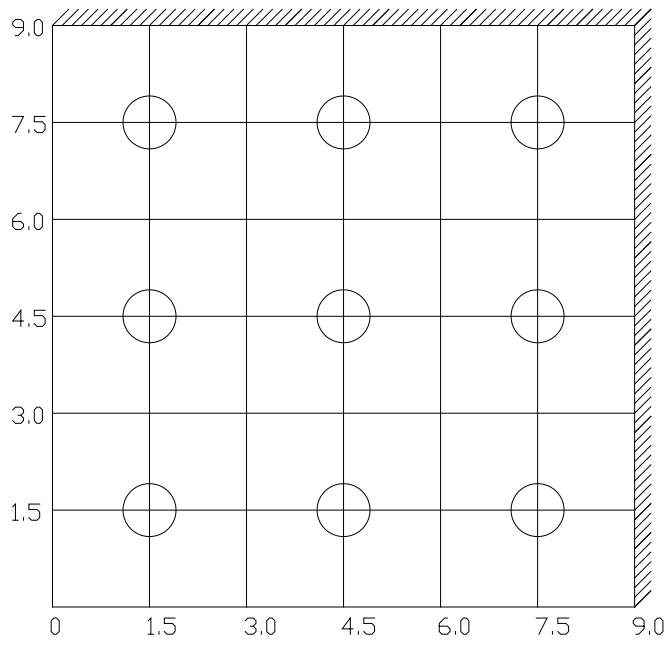

(a) 1/4 model plan

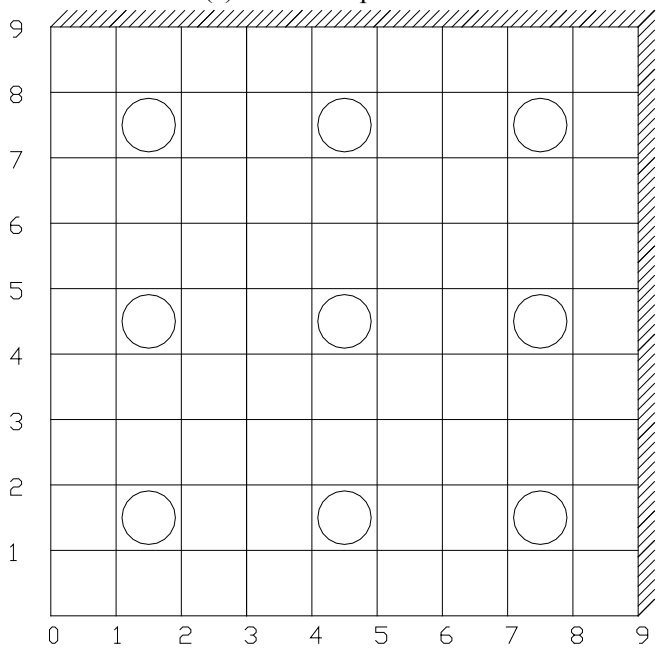

(c) $1 / 4$ model plan put in the lattice with the density being $1,0 \mathrm{~m}$. The effects of the density, the existence of the piles, and the position of the piles on the maximum rebound value are shown in Chart 3 and Fig. 3.

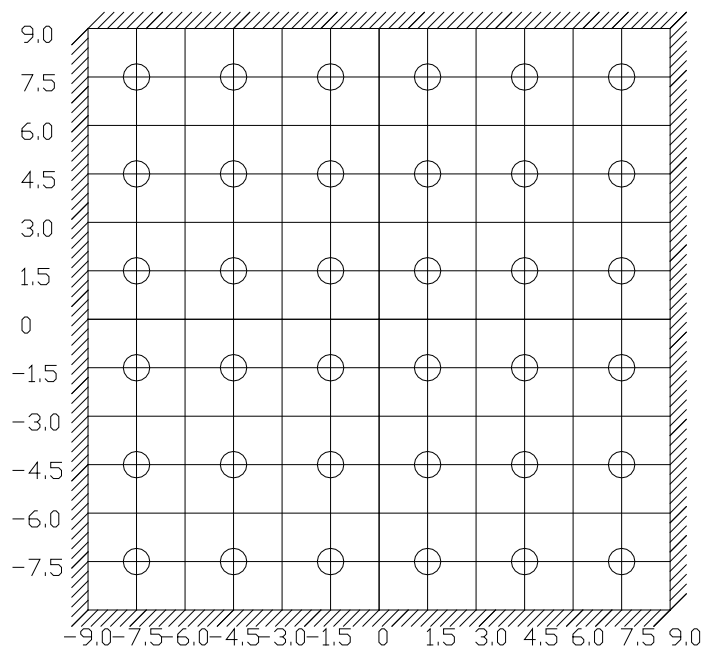

(b) The whole model plan

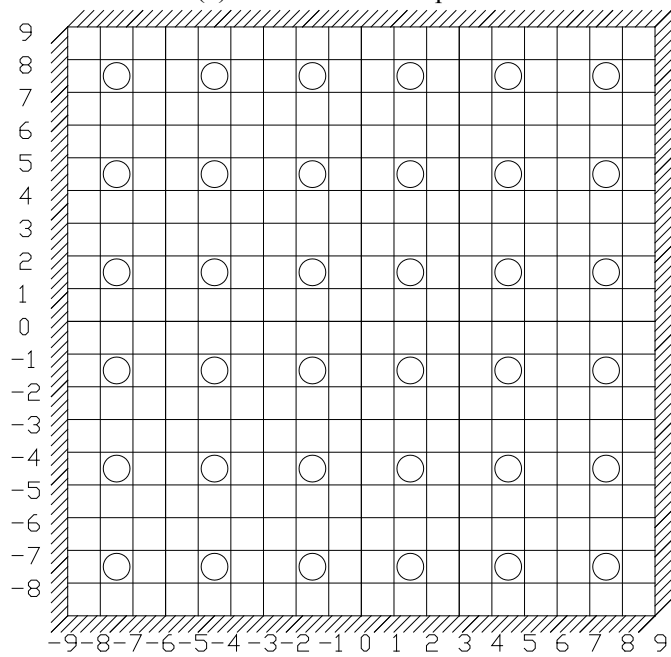

(d) The whole model plan

Figure 3 The grid plan

According to Fig. 4, in the same-sized foundation pits without piles, the rebound value increases as the density of the grid increases. Chart 4 shows that the rebound value under the density of $1,0 \mathrm{~m}$ is $0,68 \div 0,99$ times that under 1,5 $\mathrm{m}$ density. The growing digging depth brings the ratios to approach each other. In other words, when the digging depth rises, the effect of the density of the grid on the rebound value decreases. What can also be 
concluded from Fig. 4 is that in the same-sized pits, when the piles are put on the nodes, the maximum rebound value is bigger than that when the piles are in the lattice. Chart 5 reflects that the value under the latter condition is $0,71 \div 0,95$ times that under the former condition. But the growing digging depth makes the ratios increasingly similar to each other. Fig. (b) and (d) show that if the density of the grid remains the same, then the ratios remain similar. Therefore, to make the study more practical, the later part of this paper takes (d) as the research subject.

Table 3 The changing pattern of the maximum rebound values according to the digging depth considering the effect of the grid

\begin{tabular}{|c|c|c|c|c|}
\hline Digging depth $(\mathrm{m})$ & $\begin{array}{c}\text { Piles in the lattice } \\
(1,0 \times 1,0)\end{array}$ & $\begin{array}{c}\text { Piles on the nodes } \\
(1,5 \times 1,5)\end{array}$ & $\begin{array}{c}\text { Without piles } \\
(1,0 \times 1,0)\end{array}$ & $\begin{array}{c}\text { Without piles } \\
(1,5 \times 1,5)\end{array}$ \\
\hline 2 & 2,7 & 3,8 & 2,6 & 3,8 \\
\hline 5,3 & 8,5 & 10,5 & 7,9 & 10,5 \\
\hline 8,6 & 16,5 & 17,9 & 16,7 & 18,5 \\
\hline 11,9 & 20,3 & 21,3 & 21,6 & 23,6 \\
\hline 15,2 & 22,658 & 23,2 & 28,6 & 29,6 \\
\hline 18,5 & 23,3 & 24,5 & 35,1 & 36,4 \\
\hline 20 & 22,5 & 23,7 & 37,2 & 37,7 \\
\hline
\end{tabular}

Table 4 The comparison of the maximum rebound values under grids of different densities without piles

\begin{tabular}{|c|c|c|c|}
\hline Digging depth $(\mathrm{m})$ & Ratio & $1.0 \mathrm{~m}$ & $1.5 \mathrm{~m}$ \\
\hline 2 & 0,68 & 2,6 & 3,8 \\
\hline 5,3 & 0,75 & 7,9 & 10,5 \\
\hline 8,6 & 0,90 & 16,7 & 18,5 \\
\hline 11,9 & 0,92 & 21,6 & 23,6 \\
\hline 15,2 & 0,97 & 28,6 & 29,6 \\
\hline 18,5 & 0,96 & 35,1 & 36,4 \\
\hline 20 & 0,99 & 37,2 & 37,7 \\
\hline
\end{tabular}

Table 5 The comparison of the maximum rebound values with piles in different positions of the grid

\begin{tabular}{|c|c|c|c|}
\hline Digging depth $(\mathrm{m})$ & Piles in the lattice $(1,0 \times 1,0)$ & Piles on the nodes $(1,5 \times 1,5)$ & Ratio \\
\hline 2 & 2,7 & 3,8 & 0,71 \\
\hline 5,3 & 8,5 & 10,5 & 0,81 \\
\hline 8,6 & 16,5 & 17,9 & 0,92 \\
\hline 11,9 & 20,3 & 21,3 & 0,95 \\
\hline 15,2 & 22,0 & 23,2 & 0,95 \\
\hline 18,5 & 23,3 & 24,5 & 0,95 \\
\hline 20 & 22,5 & 23,7 & 0,95 \\
\hline
\end{tabular}

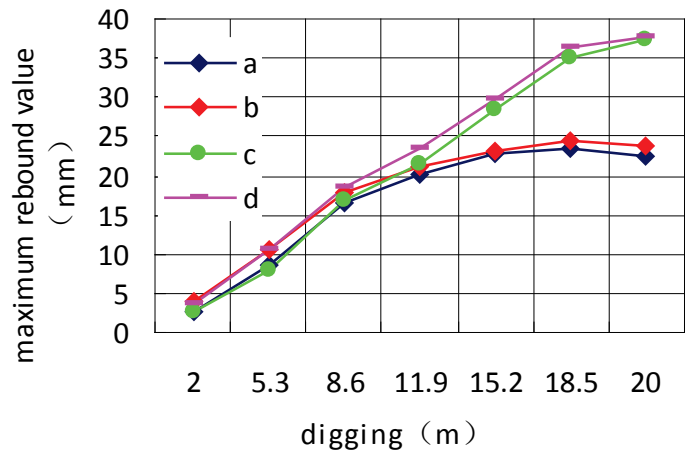

Figure 4 The maximum rebound values according to the digging depth considering the effect of the grid: $a$ - piles in the lattice $(1,0 \times 1,0) ; b-$ piles on the nodes $(1,5 \times 1,5)$; $\mathrm{c}-$ without piles $(1,0 \times 1,0)$; $\mathrm{d}-$ without piles $(1,5 \times 1,5)$

\subsection{Changing the distance between the piles}

Let $L=25 \mathrm{~m}, d=0,8 \mathrm{~m}$, the embedment of the piles be $20 \mathrm{~m}$ and Poisson's ratio $v=0,3$. Change the breadth of the foundation pit and find out the changing patterns of the maximum foundation rebound value.

Fig. 5 shows that the bigger the distance is, the less restriction on rebound is. When distance between the piles $s=3 d$, the establishment of piles can reduce the rebound value by two times. When $s=8 d$, the piles have almost no effect and when $s=7 d$, the effect is also weak with the rebound value decreasing by approximately $0,14 \div 0,18$. However, when $s=6 d$, the piles play a relatively strong effect with rebound value decreasing by $0,23 \div 0,37$. So this paper suggests that $s$ is no bigger than $6 d$ [13]. Moreover, the bigger the distance is, the less restriction of the supporting structure on the rebound value of the edge of the foundation pit is. When $s=3 d$, the rebound value of the edge is negative which is very little, meaning a little sedimentation. When $s=8 d$, the value of the edge is approximately half of that in the middle. 


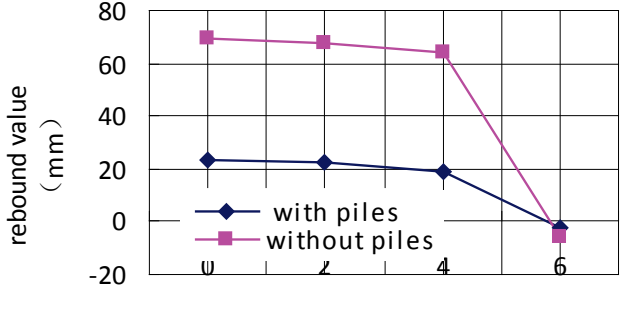

$6.0 \mathrm{~m}$ width of the foundation pit $(\mathrm{m})$ (a) $s=3 d$

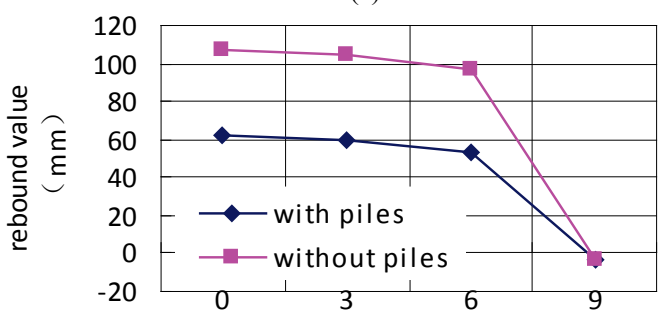

$9 m$ width of the foundation pit $(m)$

(c) $s=5 d$

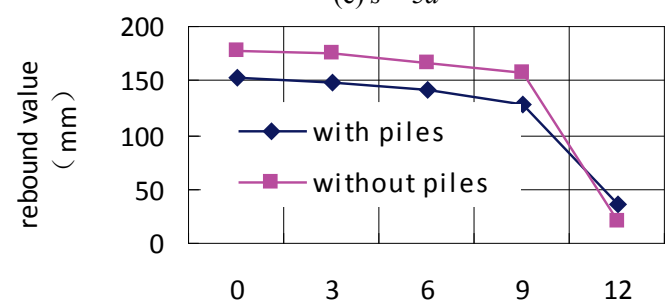

$12 \mathrm{~m}$ width of the foundation pit $(\mathrm{m})$ (e) $s=7 d$

\[ (\mathrm{e}) s=7 d \]
Figure 5 Comparison of the effects of piles on foundation pit rebound while changing the plan size of the foundation pit

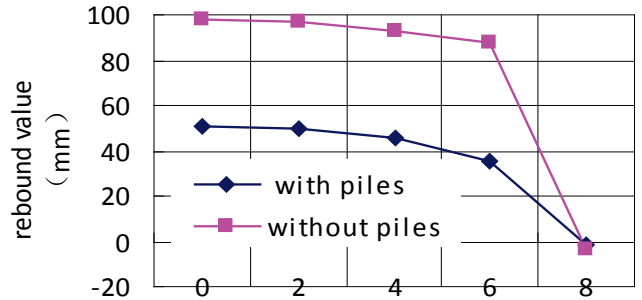

$8 m$ width of the foundation pit $(m)$

(b) $s=4 d$

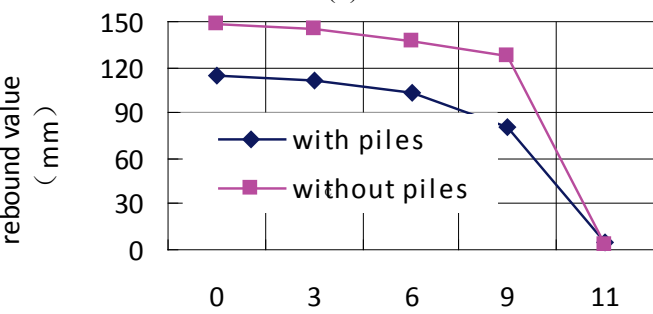

$11 \mathrm{~m}$ width of the foundation pit $(\mathrm{m})$ (d) $s=6 d$

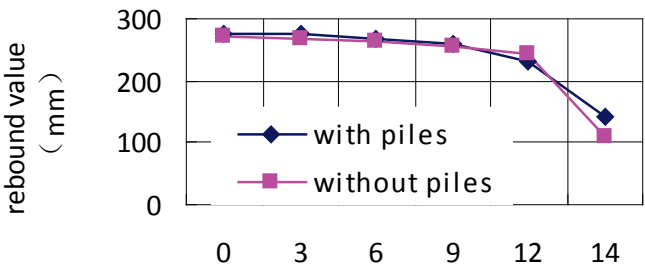

$14 \mathrm{~m}$ width of the foundation pit $(\mathrm{m})$

$$
\text { (f) } s=8 d
$$

\subsection{Changing the breadth of the foundation pit}

Given a pile whose height $L=25 \mathrm{~m}$, diameter $d=0,8$ $\mathrm{m}$, the embedment depth is $20 \mathrm{~m}$ and Poisson's ratio $v=$ 0,3 , change the breadth of the foundation pit $\mathrm{B}$ and find out the changing pattern of the maximum foundation rebound value.

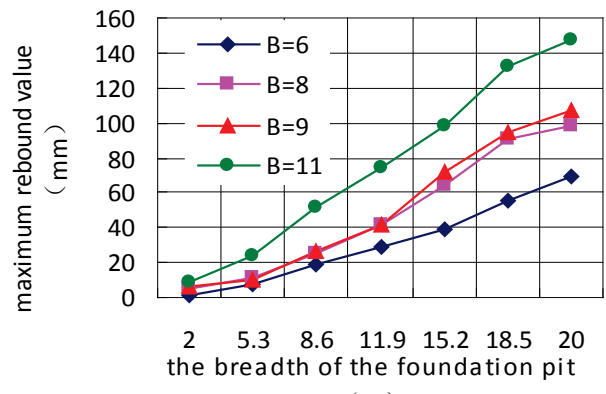

$(\mathrm{m})$

Figure 6 The changing pattern of the maximum foundation rebound value according to the breadth of the foundation pit without piles

Figs. 6 and 7 prove that the maximum foundation rebound value and the breadth of the foundation pit are positively correlated. When the piles are embedded 20 meters deep underground, their restriction on the 20meter-deep rebound and the breadth of the foundation pit are negatively correlated. The four rebound curves come to a turning point when the digging depth is $15,2 \mathrm{~m}$. That shows when piles are set 20 meters underground, they can lower the rebound value of some areas of soil that is over 20 meters $(15,2 \div 20 \mathrm{~m})$ deep. When B is $12,16,18,22$, the value decreases by $0,11 \div 0,66,0,20 \div 0,48,0,18 \div 0,42$, $0,06 \div 0,30$ respectively. So with piles, when the area of the foundation pit gets smaller, the soil rebound over the pile foundation is affected more.

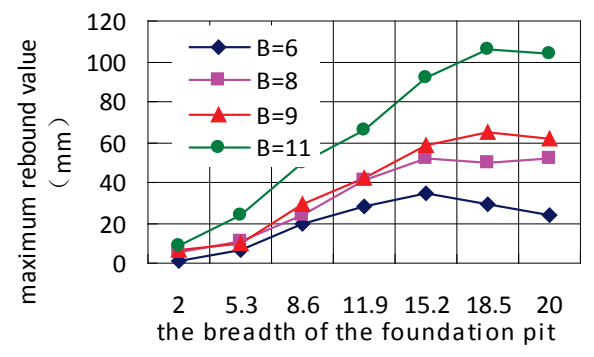

$(\mathrm{m})$

Figure 7 The changing pattern of the maximum foundation rebound value according to the breadth of the foundation pit with piles

\subsection{Changing the diameter of the piles}

Given a foundation pit with $B=9 \mathrm{~m}$, piles with $L=$ $25 \mathrm{~m}$, embedment depth being $20 \mathrm{~m}$ and Poisson's ratio $v$ $=0,3$, change the diameter of the piles and see the changing pattern of the maximum foundation rebound value according to the digging depth.

Fig. 8 shows that increasing the diameter can lower the rebound value effectively, but can add to construction cost. Therefore, as long as the rebound value meets the standard, this method should not be applied. 


\subsection{Changing the length of the piles}

Given a foundation pit with $B=9 \mathrm{~m}$, piles with $d=$ $0,8 \mathrm{~m}$, the embedment depth being $20 \mathrm{~m}$ and Poisson's ratio $v=0,3$, change the length of the piles and conclude the changing pattern of the maximum foundation rebound value according to the digging depth.

In Fig. 9, when the pile gets longer, the foundation rebound value gets smaller. However, it does not mean the longer, the better. When the length of the pile $L=25$ $\mathrm{m}$ which is 1,25 times that of the digging depth, increasing $L$ has very little impact on lowering rebound value. Therefore, $L=25 \mathrm{~m}$ is the best choice economically.

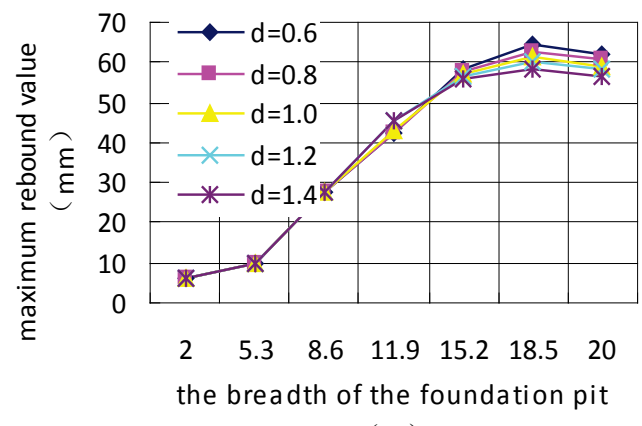

( $m$ )

Figure 8 The changing pattern of the maximum rebound value according to the digging depth for piles of different diameters

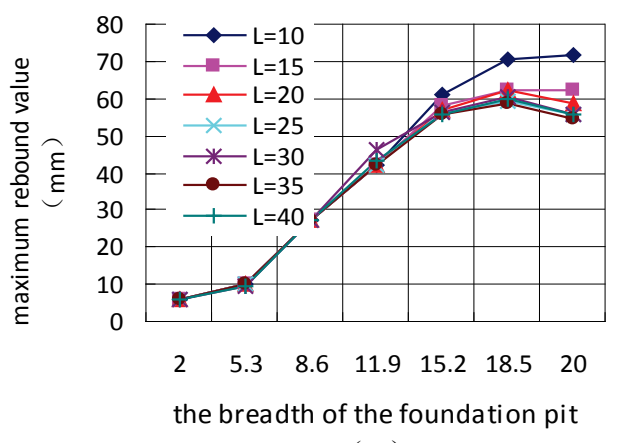

( $\mathrm{m}$ )

Figure 9 The changing pattern of the maximum rebound value according to digging depth for piles of different diameters

\subsection{Comparisons of the rebound values with and without piles}

Given $B=9 \mathrm{~m}, d=0,8 \mathrm{~m}, L=25 \mathrm{~m}$, the embedment length being $20 \mathrm{~m}$ and Poisson's ratio $v=0,3$, compare the rebound values with and without piles in the intersection line of two surfaces $z=20 \mathrm{~m}, y=1,5 \mathrm{~m}$.

Fig. 10 illustrates the numerical imitation result of foundation rebound with and without piles. Without piles, the rebound curve is convex with the middle part bulging and the edge part rebounding to a smaller degree, indicating little sedimentation. With piles, the rebound curve goes corrugated and the trough parts stand for the existence of the piles. Due to the pulling force of the piles to their surrounding soil, the latter undergoes little rebound while the soil between the piles rebounds to a larger degree [14]. Compared with no piles, the existence of piles weakens rebound. Under the same condition, rebound decreases by $0,4 \div 0,6$ with piles [15].
Table 6 The comparison of the rebound values with and without piles in the intersection line of $z=20 \mathrm{~m}, y=1,5 \mathrm{~m}$

\begin{tabular}{|c|c|c|c|}
\hline $\begin{array}{c}z=20 \mathrm{~m} \\
y=1,5 \mathrm{~m}, \\
x=\end{array}$ & $\begin{array}{l}\text { With piles } \\
(1,5 \times 1,5)\end{array}$ & $\begin{array}{l}\text { Without piles } \\
(1,5 \times 1,5)\end{array}$ & Ratio \\
\hline 0 & 26,4 & 43,2 & 0,61 \\
\hline 0,5 & 23,7 & 42,2 & 0,56 \\
\hline 1 & 20,3 & 41,1 & 0,49 \\
\hline 1,5 & 18,9 & 40 & 0,47 \\
\hline 2 & 20,3 & 38,7 & 0,52 \\
\hline 2,5 & 22,2 & 38 & 0,58 \\
\hline 3 & 24,7 & 37,2 & 0,66 \\
\hline 2,5 & 22,8 & 36,7 & 0,62 \\
\hline 4 & 19,1 & 36,3 & 0,53 \\
\hline 4,5 & 16,8 & 35,9 & 0,47 \\
\hline 5 & 18,1 & 35,5 & 0,51 \\
\hline 5,5 & 22,2 & 35,1 & 0,63 \\
\hline 6 & 23,4 & 34,7 & 0,67 \\
\hline 6,5 & 20 & 33 & 0,61 \\
\hline 7 & 14,7 & 32,2 & 0,46 \\
\hline 7,5 & 12,2 & 27,9 & 0,44 \\
\hline 8 & 9,2 & 21,6 & 0,43 \\
\hline 8,5 & 5,7 & 12 & 0,48 \\
\hline 9 & 2,9 & 3,2 & 0,91 \\
\hline
\end{tabular}

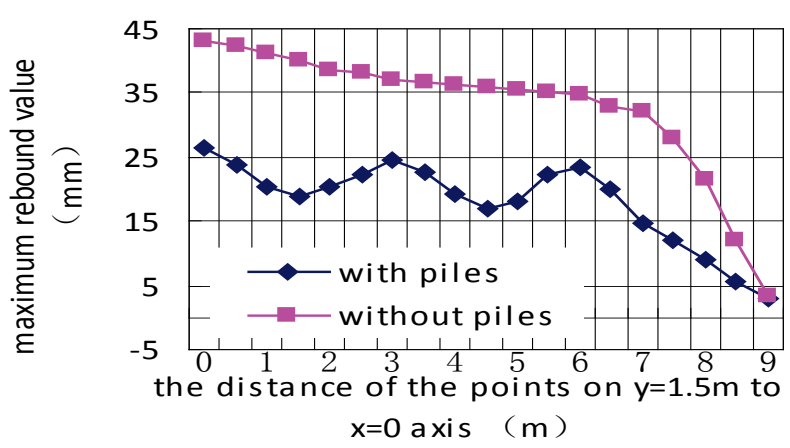

Figure 10 Comparison of the rebound values with and without piles

However, piles do not always consolidate soil in the pit under any circumstance. The consolidation depends on the influence of the piles on the soil and the time of digging the pit. If the piles are displacement piles, the consolidation time is short so the intensity of the soil in the pit is reduced to some extent. If the piles are nondisplacement piles (for most of the time), then the piles can consolidate the soil, which is good for controlling the foundation rebound.

\section{Conclusion}

To conclude, plan 3 shows that the rebound data extracted from the central axis form a convex rebound curve while the data from the central line of the pile form a corrugated curve. This is because the axis is located in the middle of the neighboring two piles and all the points in the axis represent the crest values.

Put the piles 20 meters underground and let the digging depth be $D$, then the piles can consolidate the soil between $0,25 D$ above the foundation and $1,25 D$ below it, restricting soil rebound effectively.

The distance between the piles and the restriction on soil rebound forms a negative correlation while the diameter of the piles and the restriction on the rebound form a positive correlation. 
The density of the grid and the position of the piles, whether on the nodes or in the lattice, have little impact on the analysis of the maximum rebound value.

\section{References}

[1] Sharp, M.; Hwang, C. Pile driveability and bearing capacity in high-rebound soils. // GeoCongress 2006, pp. 1-4.

[2] Jarushi, F.; Cosentino, P. J.; Kalajian, E. H. Prediction of High Pile Rebound with Fines Content and Uncorrected Blow Counts from Standard Penetration Test. // Transportation Research Record: Journal of the Transportation Research Board. 2363, 1(2013), pp. 47-55.

[3] Jarushi, F.; Cosentino, P. J.; Kalajian, E. H. Piezocone Penetration Testing in Florida High Pile Rebound Soils. // DFI Journal: The Journal of the Deep Foundations Institute. 7, 2(2013), pp. 28-45.

[4] Jarushi, F.; Cosentino, P. J.; Kalajian, E. H. Using Fines Content and Uncorrected SPT Blow Counts of Soils to Predict High Pile Rebound. // Journal of the Transportation Research Board, 2013.

[5] Cosentino, P. J.; Kalajian, P. E. E. H.; Jarushi, P. E. F. et al. Identifying High Pile Rebound Soils Using CPT Pore Water Pressure Measurements: Case Studies in Florida. // Transportation Research Board $92^{\text {nd }}$ Annual Meeting. 2013 (13-2871).

[6] Yang, Y.; Ma, Y.; Zhang, X. et al. Anchored and Statically Pressed Pile with Axial Prestress and Its Application in Uneven Settlement Treatment of Bridge Piles in Soft Soils. // Bridges. 10, (2014), 9780784412442.333.

[7] Zheng, Gang; Jiao, Ying. Design Theory and Engineering Application of Deep Foundation Pit Engineering. // Beijing: China Building Industry Press. 12, (2010).

[8] Liu, Guobin; Wang, Weidong. Excavation engineering handbook. // Beijing: China Building Industry Press. 11, (2009).

[9] Sun, Shuwei; Lin, Hang; Ren, Lianwei. The application of Flac3D in geotechnical engineering. // Beijing: China Water Conservancy and Hydropower Press. 194, (2011).

[10] Xiao, Zhaoran. Determination of Hyperbolic Model and Its Corresponding Parameters in Single-pile Analysis. // Soil Engineering and Foundation. 16, 3(2002), pp. 60-64.

[11] Chen, Yuming; Xu, Dingping. Basics and Engineering Examples of FLAC/FLAC3D. // Beijing: China Water Conservancy and Hydropower Press. 2009.

[12] Liu, Bo; Han, Yanhui. Principles, Cases and Application Guida of FLAC. // Beijing: China communication press, 2005.

[13] JGJ94-2010 Technical codes for building pile foundation $[\mathrm{S}]$.

[14] Xiao, Jian. Rebound spatial effect of deep foundation finite element analysis considering the existence of engineering pile. // Master's degree thesis of Tianjin University, 2004.

[15] Lu, Pei-yi; Yu, Jian-xing; Xiao, Jian. Three-Dimensional Properties of Foundation Pit Resilience under Unloading. // Journal of Tianjin University. 39, 3(2006), pp. 301-305.

\section{Authors' addresses}

Zhiyuan Li, doctoral student

College of Architecture and Civil Engineering,

Taiyuan University of Technology

Chongqing Water Resources and Electric Engineering College 801, Changzhou East Avenue, Yongchuan, Chongqing, 402160,

China

E-mail:1628607391@qq.com
Ren-Wang Liang, professor and doctoral supervisor

College of Architecture and Civil Engineering,

Taiyuan University of Technology

79, Yingzexi Street, Taiyuan, Shanxi, 030024, China

E-mail: lrw1962@163.com

\section{Long-Sheng Zou, Postdoctoral}

Chongqing Water Resources and Electric Engineering College 801, Changzhou East Avenue, Yongchuan, Chongqing, 402160 China

E-mail: sh1211@163.com

\section{Yanmei Zhang, master}

Chongqing Water Resources and Electric Engineering College 801, Changzhou East Avenue, Yongchuan, Chongqing, 402160, China

E-mail: woai.zhangyanmei@163.com 